This item was submitted to Loughborough's Research Repository by the author.

Items in Figshare are protected by copyright, with all rights reserved, unless otherwise indicated.

\title{
Gender in the UK architectural profession: (re) producing and challenging hegemonic masculinity
}

\section{PLEASE CITE THE PUBLISHED VERSION}

http://dx.doi.org/10.1177/0950017013491306

\section{PUBLISHER}

SAGE Publications / @ The Author(s)

VERSION

AM (Accepted Manuscript)

\section{PUBLISHER STATEMENT}

This work is made available according to the conditions of the Creative Commons Attribution-NonCommercialNoDerivatives 4.0 International (CC BY-NC-ND 4.0) licence. Full details of this licence are available at: https://creativecommons.org/licenses/by-nc-nd/4.0/

\section{LICENCE}

CC BY-NC-ND 4.0

\section{REPOSITORY RECORD}

Sang, Katherine J.C., Andrew R.J. Dainty, and Stephen G. Ison. 2019. "Gender in the UK Architectural Profession: (re) Producing and Challenging Hegemonic Masculinity”. figshare. https://hdl.handle.net/2134/17761. 


\title{
Gender in the UK Architectural Profession: (re)producing and challenging hegemonic masculinity.
}

Katherine J C Sang, Centre for Research on Work and Well-Being, School of Management and Languages, Heriot Watt University, Edinburgh, EH14 4AS k.sang@hw.ac.uk

Andrew R J Dainty, Department of Civil and Building Engineering, Loughborough University, LE11 3TU, a.r.j.dainty@lboro.ac.uk

Stephen G Ison Department of Civil and Building Engineering, Loughborough University, LE11 3TU, s.g.ison@lboro.ac.uk

\begin{abstract}
Architecture represents a creative, high profile and influential profession, and yet remains under-theorised from a gender perspective. This article examines how gender is (re)produced in architecture, a profession that remains strangely under-researched given its status and position. The empirical work advances the theoretical concept of hegemonic masculinity via an analysis of gendered working practices and the agency of individuals through resistance and complicity with these norms. It reveals how architectural practice relies on long working hours, homosocial behaviour and creative control. However, whereas women perform their gender in ways which reproduce such gendered norms, white, heterosexual, middle class men can transgress them to challenge aspects of practice culture. This has significant implications for understanding the ways in which hegemonic masculinities are reproduced within creative workplaces.
\end{abstract}

Keywords: architects, gender, homosocial behaviour, masculinity, professional work, social networks, work-life balance, working hours 


\section{Introduction}

Strong links have been made between masculinity and professionalism (Connell, 1987), for example, within management, where professional identity has been demonstrated to be closely tied to a competitive masculinity (Meriainen et al., 2004). That is, to be professional is to be masculine, although not all professions adopt a unitary masculinity (Dent and Whitehead, 2002). This article examines gendered working practices within the UK architectural profession where women remain significantly under-represented, a situation which has worsened in recent years (Fulcher, 2010). Architects work in the construction industry, a sector which exhibits a highly masculine working environment where women (Ness, 2012, Watts, 2007; 2009) and marginalised men (Denisson, 2010) experience difficulties participating fully in the labour market. Despite a body of literature identifying the difficulties faced by women architects (Caven, 2005; Fowler and Wilson, 2004, deGraft Johnson et al., 2005), male architects remain unexamined. Understanding masculinities can develop gender research beyond essentialist approaches that emphasise male and female. Specifically, the study of masculinity allows for an analysis of the 'performative nature of gender' and its maintenance through 'everyday practices’ (Fournier and Smith, 2006: 141). Using the lens of hegemonic masculinity, this article examines how gender is (re)produced in the architectural profession that remains strangely under-researched given its status and position (cf. Cohen et al. 2005). The empirical work presented here advances the theoretical concept of hegemonic masculinity via an analysis of gendered working practices and the agency of individuals through resistance and complicity with these norms. The article outlines the current literature on gender in the workplace, specifically the role of paid employment in the (re)production of gender inequality, hegemonic masculinity and briefly outlines the working conditions of architects. The qualitative methodology used to understand 
gendered working practices in the architectural profession is detailed and the findings, theoretical and practical implications of the study for our understanding of workplace gender inequality are then discussed.

\section{Gender inequality}

Gender is performed and reproduced in ways that perpetuate gender inequality within organisations (Acker, 1990). Professional identities are socially constructed in gendered ways that are used to justify the continued dominance of men and supposed unsuitability of women for full time employment (Dick and Cassell, 2004). Women may choose self-employment in order to balance their paid and domestic work (Craig, Powell and Cortis, 2012), but professional women who work flexibly, balancing work and family, face a career and earning penalty relative to their male counterparts (Smithson et al., 2004). A recent study on knowledge workers shows that women work fewer hours than male colleagues, earn lower salaries and are less likely to reach senior roles (Truss et al., 2012). Despite evidence that attitudes towards maternal employment in the UK are shifting away from traditional roles (Schober, and Scott, 2012) combining paid work and family duties are still considered the domain of women (Jyrkinen and McKie, 2012). As Crompton (2010) argued in her analysis of class inequality, the capitalist structure of the labour market results in the uneven distribution of rewards that in turn (re)produces inequality. This is seen as natural and can therefore be characterised as hegemonic. Gendered hegemony has become naturalised, with the acceptance and complicity of women (Dick and Cassell, 2004). However, such structuralist arguments do not allow for an analysis of the role of agency or of individual complicity and resistance in the (re)production of inequalities (Whitehead, 2002). 
The concept of hegemony has been used to understand gender relations, particularly masculinities (Donaldson, 1993) in the form of hegemonic masculinity 'the currently most honored way of being a man' (Connell and Messerschmidt, 2005: 4). Within modern Western society the practice of hegemonic masculinity is referred to as 'macho, tough, competitive, self-reliant, controlling, aggressive and fiercely heterosexual' (Bradley 2007: 47), with men building alliances with each other, often socialising outside work (Collinson and Hearn, 1994). Kanter (1977: 48) argued that men prefer the company of other men, a phenomenon she called 'homosocial behaviour', that serves to exclude women from informal networks and thus ensures men's continued control of organisational resources (Martin and Collinson, 1999). Hegemonic masculinity, like all identities, has to be continually 'constructed, negotiated and achieved both in the workplace and elsewhere' (Collinson, 2003: 533) and is achieved through identification with those who embody hegemonic masculinity and is distinguished from subordinated/marginalised masculinities and women (Collinson and Hearn, 1994). A central element of hegemonic masculinity is that it is relational; it is what women and subordinated masculinities are not, relying on a (false) dichotomy between the masculine and the feminine. For example, male heterosexual Naval Officers in the USA have been shown to actively construct their masculinity in opposition to women and nonheterosexual men (Barrett, 1996). They do so by working to outperform, discount and negate 'others' (Collinson, 2003), including women and sub-ordinated masculinities such as homosexuals, the softer 'New Man’ and ethnically different masculinities (Bradley, 2007).

Hegemonic masculinity is not without its critics. Demetriou (2001) argues for a return to Gramsci's work and his concept of a hegemonic bloc that unites the hybrid masculinities who are allies in the reproduction of the patriarchy. Further, discussions of hegemonic masculinity are often limited to structural explanations of male power, with little examination of the 
complicity and resistance of individuals (Whitehead, 2002). Moller (2007) argues that the researcher himself (note the assumption that the masculinities scholar is male) often fails to engage with an analysis of their own masculine privilege. However, Moller (2007) suggests that hegemonic masculinity can be useful in contexts where the (male) actors exhibit a uniformity that is formed by corporate contexts. Studies of hegemonic masculinity run the risk of essentialism, conflating masculinity with men and femininity with women. Schippers (2007) offers a way to address this, arguing the social locations of 'man' and 'woman' are the places where characteristics of masculinity or femininity are embodied or displayed. Borrowing from West and Zimmerman (1987), this conceptualisation allows for an understanding of how the social places of man and woman (and the resulting hierarchies) are related to the ‘doing gender’ of masculinity and femininity (Powell et al., 2009).

Further work is required to understand the agency of subordinated and marginalised groups calling for greater understanding of ‘the practices of women’ (Connell and Messerschmidt (2005: 848) and men (Whitehead, 2002). Much of the current work on hegemonic masculinity focuses on masculinities, with femininities largely absent from the discussion, although femininities are present in Connell's (1987) framework which identifies emphasized femininity, the 'compliance with this subordination [of women to men] and is orientated to accommodating the interests and desires of men...others are defined centrally by strategies of resistance or forms of non-compliance. Others again are defined by complex strategic combinations of compliance, resistance and co-operation' (pp. 184-185). Schippers (2007:102) builds on this definition adding that what she calls hegemonic femininity is related to the characteristics which are defined as 'womanly [and] that establish and legitimate a hierarchical and complementary relationship to hegemonic masculinity' and this ensures the domination of women by men. This contrasts with Connell (1987) who argues 
that given the universal subordination of women by men, femininity can never be hegemonic. Debating whether femininities can be hegemonic or emphasized offers little about what women (as the place where femininities are practiced) actually do in order to resist or re(produce) gender relations. There is a lack of understanding of those who transgress hegemonic masculinity beyond not being white, heterosexual, middle-class and motherhood. In particular, much of the current, albeit limited, work on masculinity in organisations, has focussed on non-white, gay, working class men, or women who have become mothers. This article addresses this through an analysis of the architectural profession, where women fail to progress on equal terms with men.

\section{The architectural profession}

Architecture, both in its practice and outputs, is gendered (Domosh, 2005), resulting in buildings designed to serve the needs of a patriarchal (and heterosexual) family structure (Bonnevier, 2007). Boys (1984) argued the built environment has been designed around male, middle class, white norms, evidenced by, for example, the difficulties faced by women with push-chairs navigating city streets. Bonnevier (2007) has further argued that all building activities perpetuate existing cultural and societal norms. Using the framework of performativity, Bonnevier (2007) argues that engaging in building activities helps to partially construct subject positions.

The UK architectural profession is male dominated with women representing less than $20 \%$ of registered architects (Fulcher, 2010) and 13\% of chartered architects (deGraft-Johnson et al., 2007). Ethnic minorities comprise 6.6\% of architects (CABE, 2005) and those with disabilities under-represented within the UK architectural profession although exact figures 
are difficult to determine (deGraft-Johnson et al., 2009). Fowler and Wilson (2004) offer insight into the gendered working experiences of architects highlighting the masculine working cultures. Older male architects argue that women (especially those with children) lack the commitment and aggression required to be an architect. Younger male architects spoke optimistically of a changing and liberal profession where women can compete equally, while suggesting women lack the technical abilities to undertake 'construction stuff' with their children suffering by not being cared for by a biological parent. The image of the profession is one of a 'good architect' as incompatible with being a 'good' parent (Stratigakos, 2008). Fowler and Wilson (2004) and Greed (1994) suggest gendered assumptions are made about what it takes to be an architect, specifically the lack of progress by women and it is argued to be the result of women's 'unsuitability' for architectural work. It would therefore appear to be a good architect a person must be male (Greed, 1994) and indeed embody a certain kind of masculinity.

Much of the empirical work examining female architects' under-representation has focussed on the impact that having a child has on a woman's career (Caven, 2005, deGraft Johnson et al., 2005; Fowler and Wilson, 2004), with much appearing to assume that men and women are two distinct homogeneous groups. In reality, there are multiple masculinities, specifically hegemonic masculinities and subordinate masculinities (Collinson and Hearn, 1994). The lens of hegemonic masculinity is used in this article to gain an understanding of the gendered working relations within architectural practice. Taking hegemonic masculinity to be a ‘configuration of gender practices’ (Connell, 2002: 77) allows for gender relations in the architectural profession to be understood through an analysis of the everyday practices of architects. 


\section{The current study}

Adopting an interpretative approach this study assumes that gender is socially constructed, a perspective adopted in similar studies, for example Pullen and Simpson (2009), and Kelan (2008). Accordingly, a qualitative approach enabled respondents to provide rich descriptions of their experiences (Richards, 1999), while providing scope for the researcher to pursue interesting lines of reasoning (Johnson and Turner, 2003).

The data were collected via a series of semi-structured interviews. An interview schedule was developed from the existing literature that shows that gender affects architects' experiences of their working lives (Caven, 2004; deGraft-Johnson et al., 2005; Fowler and Wilson, 2004). Interviews covered a range of themes selected in order to understand architects' experiences and perceptions of their working lives. Topics included; reasons for choosing the profession, educational experiences, career progression, practice management, relationships with colleagues, other construction occupations and clients and their scope for creativity. Respondents were asked about how they balanced their working and non-working lives and satisfaction with work. The interview schedule was flexible and provided scope for participants to raise issues of importance.

Twenty-three semi-structured interviews were conducted with UK practicing architects. Thirteen respondents identified themselves as male, and ten female. Twenty-two were employed full time. Eighteen identified themselves as White British. Their ages ranged from 25 to over 60 . Table 1 outlines the interview sample. All were informed of the purpose of the study prior to the interviews and guaranteed anonymity (only first names or pseudonyms are used in the findings section) and that their responses would not be shared with their practices 
(where relevant). All were informed of their right to withdraw from the study at any time without providing explanation.

Interviews lasted between 60 and 90 minutes, were recorded (with one exception where notes were taken) and transcribed verbatim. Interviews took place in a location of the architect's choosing, often a private room in their place of work or a nearby café. The resulting transcripts were analysed thematically using template analysis (King, 2004) enabling thematic analysis of text using the initial interview schedule as base codes along with emergent themes (Mustchin, 2012; Cassell and Lee, 2009). The interview schedule was used as the initial coding framework (for example, work life balance). Themes and sub-themes that emerged from the data (for example technological expertise) were incorporated resulting in the final coding template. Following this approach ensured that analysis was guided by the extant literature while retaining the flexibility for emergent themes to be incorporated (Pritchard and Symon, 2011), remaining consistent with the interpretive framework of the study (Waring and Wainwright, 2008).

Three aspects of the interviewer/respondent relationship are important when considering the data presented. First, the interviewer is not an architect. During the course of the interviews, respondents had to clarify aspects of architectural practice that would have been familiar to an architect (or other construction professional). This encouraged respondents to make explicit some of their tacit knowledge of the profession. Lupton (2000) has suggested that where the interviewer and respondent have a shared identity the interviewer may unintentionally advance a particular view of that shared identity. This may be problematic given the inherent power imbalance of the interview relationship. Second, the interviewer was not known to the respondents and this may have encouraged a level of openness that may 
not have been forthcoming if there had been a prior relationship. Third, the interviewer was female. Previous work exploring masculinities has suggested that men may be less likely to reveal details of their lives to a female interviewer (Lupton, 2000). Lindebaum and Cassell (2010) have suggested that male construction professionals may give differing responses to a male or female interviewer. The level of personal detail shared by both the male and female respondents suggests they were comfortable sharing this information with a female researcher they did not know personally.

[Insert Table 1 here]

\section{Findings}

\section{A culture of long working hours}

When asked about their working conditions and work-life balance, a long working hours culture, in the region of '60 or 70 hours a week' (Sara, female, partner, 30's) was reported as a key element of working life by all the architects. As Helen describes:

I rarely take lunch breaks, I am often in work at least half an hour extra each day so that's an hour and a half a day typically, so an extra day a week. Quite often I can be working two or three hours later in the evening (Helen, female, partner, 30s).

In addition to evening working, architects also reported having to work at the weekends; 'there are times when I would rather not be working at the weekend when I am' (Ian, male, married, 30s). 
The majority of male architects in the sample had children and female partners who worked part-time, with a small number having partners who did not work outside the home. When these male architects were asked how they balanced their work and family lives, the majority made no mention of their female partner. There were three older married male architects with adult children, two of whom reflected on their wives' roles as primary carers for their children. Both reported they regretted their lack of involvement with their children.

I was away early in the morning, got back late at night. So, as I say, I missed a serious part of my children growing up (James, male, married, 50s).

There were two male architects who had attempted to challenge the gendered norms: Robert and Simon. Both had considerable caring responsibilities, reporting that the pressure to separate their work and private spheres had resulted in prolonged sickness absence. Robert (male, married, 30s) stated:

I suffered from a depressive episode where I had to take nearly a month off work and that was because I was trying to look after my daughter and at the same time do my job.

Simon recalled a situation where he had been sacked from a practice. He had been taking care of his elderly mother and had been unable to work the long hours demanded of him. After this incident, Simon had taken a career break and had decided not to return to work as a practicing architect. Co-incidentally, Simon's former (female) line manager (Vanessa) was also interviewed in the current study. She recalled this situation reporting: 
I was working on a job where the project architect had a nervous breakdown and it actually took me a long while [to notice]... (Vanessa, female, married, 50s).

Vanessa attributed responsibility for this situation on Simon's apparent inability to cope, rather than reflecting on the way she had organised the workload. Vanessa seemed to have accepted the way of working within the profession relying on a person's willingness or ability to separate the two spheres of their lives, while reflecting herself that she struggled to combine her work with childcare. Vanessa was also involved in a number of initiatives aimed at changing the culture of the profession to increase the number of women architects. Despite this, she had clearly internalised the norms of the profession. She could also be seen to be reproducing hegemonic masculinity herself by terminating this person's contract rather than identifying and addressing the underlying problem and could be seen to (re)produce the gendered working patterns that serve to reinforce the gender hierarchy.

The consequences for Robert and Simon were different. Robert returned to work as an architect full-time and no longer felt marginalised, although this required his withdrawal from childcare. In contrast Simon had felt unable to continue working as an architect, and had moved to working at an architectural employment agency where he recalled his (unnamed female) line manager refusing to employ women in their late 20s and early 30s. When Simon questioned this practice that he felt was 'sexist', he was told that women of that age 'were going to go off and have babies' and were unsuitable for employment.

Only one of the female architects interviewed had children. One female architect (Katie) did report a desire to have children, but felt that women should have primary responsibility for childcare. 
I don't think I could combine working with having kids...because I'm a good old fashioned, anti-feminist kind of girl, I don't see the point in working just so you can hire a nanny. I would happily stay at home bringing up my children (Katie, female, single, 20s).

\section{Homo-social behaviour}

When discussing career progression, respondents noted the importance of predominatelymale dominated social networks with other architects, clients and construction professionals. Respondents cited examples of men preferring the company of other men, ostracising women and undermining them. Some of the women architects interviewed recalled situations where they had been excluded from valuable social networks, for example, Sara explained:

I like to think it's [promotion] on merit but I am realistic enough to know that I don't play golf at the same club. (Sara, female, partner, 30s).

These social networks are important since an architect's ability to bring project work into a practice is a key element of promotion to partner. Sara describes a situation where she felt excluded from important social activities.

I found out today that this client has phoned my boss, one of the directors, and said you have done a grand job, thanks a lot, we are going to take you out for a few beers to say thank you and I thought, hang on, you didn’t do any of that work. 
This quote illustrates two important points. Firstly, that Sara's work on a project was ignored by the client consequently; she did not receive personal recognition for her work. Secondly, the role of gendered networking activities such as golf and drinking alcohol, that women architects may be excluded from. Other women interviewees also reported that lack of access to social networks and clients had significantly hindered their career progression, as they were not able to undertake the kind of work that was believed necessary for promotion:

It took me a long time to realise I wasn’t getting good work. I was a very good assistant, sort of doing perfect amendments to drawings and backing up someone, so I didn’t really meet clients in general (Amy, female, single, 40s).

Another female respondent said she had never met the client whose project she was running. If women architects are not meeting the client then it seems probable that their contributions to projects will be ignored. In addition, meeting clients and learning how to bring work into the practice was cited by several respondents as being necessary for career progression.

Ian a young male architect argued that difficulties with working relationships can also affect younger male architects, specifically relationships with other occupational groups.

Even for most young male architects walking onto a building site for the first time you have got to have confidence and know what you are doing. If you don't a building site can be a very scary place to be because builders are very good at teasing and being difficult with young architects... (Ian male, married, 30s). 


\section{Technological expertise}

Some of the women architects interviewed reported that their technological expertise was questioned by colleagues and clients. They felt their status as architects was in question, a phenomenon not reported by any male architects. Rebecca (female, relationship status unknown, 30s) reports how conflicts with clients and contractors resulted in her professional status being questioned:

It can be difficult to make yourself heard on a site full of 50 year old men who know better than you...trying to exercise some control on site when everyone is much older than you and they definitely know much more than you 'love' can be difficult.

In addition, Rebecca had experienced difficulties with clients:

I have a particular client...he speaks to us [female architects] like little girls. It is rather patronising, as he doesn't seem to think that we know what we are talking about. That is just out and out sexist.

Rebecca's experiences reflect those reported by other women architects, that their expertise and status as an architect was questioned by colleagues and clients. Other female architects reported their access to certain tasks were restricted:

We don't get exposed to the same range of challenges as men. And it certainly used to be the case that the women did all the insides of buildings and men did the outsides 
which I challenged relentlessly and I think that it’s now less prevalent' (Vanessa, female, married, 50s).

As described earlier, Vanessa did not question the long working hours required in architecture; however, she also challenged allocation of her own work along gendered lines. Mary (a more recently qualified female architect) suggested this gendered division of labour persists in architectural practice.

I wasn’t allowed to do any exteriors. All I was given was colouring in work. (Mary, female, relationship status unknown, 30s)

These women reported being denied access to work that they felt would enable them to develop their skills as architects.

\section{Creativity}

For most architects in the study, the opportunity for design and creativity was a key motivator for training to be an architect as the following quote illustrates:

I think it [architecture] combines a couple of different things I am interested in like the artistic side and the creative side of me. (Ian, male, married, 30s).

However, the interviewees suggested that scope for creativity is largely limited to senior (male) architects. So called 'junior' architects reported frustration since creativity was seen to be the preserve of the partners in practices: 
Jobs come in and it's the partners who get them initially, so most of us don't get the work until it's a bit further down the line so you haven’t been able to have that initial creative input. (Ian, male, married, 30s).

Ian demonstrates 'creativity', the perceived defining feature of architecture, was limited to partners, i.e. those who exercise control. However, there was a suggestion amongst respondents that those in smaller practices may have greater scope for creativity. Tristan (male, married, 30s), recalled that he and his partner had established their practice with an ethos whereby all designers were able to exercise their creativity.

\section{Discussion and conclusions}

As Whitehead (2002) has argued, the practices and agency of men and women in the workplace is a gap in the current knowledge, one which this article addresses. Using the experiences of men and women architects who exhibit agency which is both resistant to and complicit with gendered norms, this study has explored the effects of these gendered working practices through the lens of hegemonic masculinity. Building on the study by Fowler and Wilson (2004), it has been revealed that women architects are still unable to participate fully, in the profession. In addition, the research has shown that men who transgress gendered norms also face significant difficulties.

Research from other sectors has revealed that creativity is seen as 'feminine' (Kenway and Fitzclarence, 1997) and reflective of a marginalised form of masculinity (Emslie et al., 2006). Creativity is an essential component of architectural practice and the data presented here shows it is not a discourse employed by the marginalised. In architectural practice, control 
over creativity rests with those in senior / managerial positions (Sage and Dainty, 2012). Traditionally within architecture, and management more generally, men occupy the positions of power (Collinson and Hearn, 1996), positions that control creativity, resulting in close ties between particular masculinities and managerial practices, in this case creativity. These managerial masculinities serve to reinforce the power of these particular men, but also the apparent 'rights' of management and 'male' managers (Collinson and Hearn, 1996: 11). As Tristan argued, within his small practice that creativity was shared amongst all designers. However, since his employees were not interviewed, the extent to which his designers would share this sentiment cannot be determined. Additionally, the data suggests that women architects find their status as architects questioned, in particular, in relation to technical expertise, an experience none of the men reported. A number of women reported that they experienced task restriction, whereby they felt unable to fully reveal their full range of technical skills. Guerrier et al (2009) demonstrate that technical competence is a key component of gender relations within organisations. The data presented here suggests that the scope to be creative within architecture acts to organise masculinities. Perceived technical competence is used by male architects to marginalise women architects, and as such further organises the gender hierarchy within architectural practice.

The culture of long working hours prevalent within the profession was not an unexpected finding. The structure of organisational life is never gender neutral as it reflects and perpetuates gendered (masculinist) expectations of work and non-working life and how they can be reconciled (Acker, 1990; Runte and Mills, 2006). These gendered working practices, by both men and women, serve to perpetuate gendered norms that marginalise women and subordinated masculinities. Indeed, adopting Gramsci's (1971) model of hegemony, the subordinated must not only be accepting of the dominant, but also be complicit. The data 
presented here supports earlier work that suggests women can be complicit in the social construction of professional identities that ultimately serve to marginalise them (Dick and Cassell, 2004). As the situation between Vanessa and Simon illustrates there can be tensions for women who wish to challenge the norms of a profession and remain in that profession, for example, engaging in gender equality activism while performing gender in ways that reinforce the very working practices they report as challenging. The interview with Vanessa showed how she was engaging in gendered working practices, in this case, firing a male coworker with caring duties while simultaneously challenging the gendered practices of others. While Vanessa was engaged in gender equality activism outside of her own practice, and challenged the gendered working practices she was subject to, she did not challenge them when they affected those under her authority. Such practices have been identified amongst women engaged in other forms of activism, for example, trade union leadership (Kirton and Healy, in press). The impact of these apparently contradictory practices has implications for gender equality measures.

Given the relatively young profile of the women in the sample and that only one woman had children is perhaps unsurprising. Glover and Kirton (2006) have argued that many professional women choose not to have children in order to pursue their career. This was not something respondents echoed, although a number did express concern over how they might balance work and family in the future. However, the arrangement of work and family life are problematic for men who transgress these gendered expectations. The majority of research on marginalised and subordinated masculinities has explored how sexuality, ethnicity and class can interact with masculinity to produce a hierarchy of masculinities. The current research takes this further by showing that white, heterosexual, middle-class men do attempt to challenge hegemonic masculinity, with considerable cost to themselves. Simon and Robert 
who both struggled and ultimately were unsuccessful in balancing their work and family life were unable to meet the gendered norms of the profession. As with Vanessa, Robert and Simon's efforts to challenge gendered working norms were largely restricted to improving their own working lives. Although Vanessa was engaged in gender equality activism and Simon questioned the gendered bias of a female line manager, these actions were not realised in consistent efforts to challenge the working practices of architects.

The current study has implications for those managing architectural practices and other organisations. If, as Segal (2007) argues, the heteronormative assumptions that dominate the arrangement of working life are changing and more men are engaging in caring responsibilities, employers who do not accommodate this social change may find difficulties recruiting and retaining highly skilled employees. However, the reliance on a heterosexual masculinity, whereby a male can be assumed to rely on a female partner to undertake unpaid caring work, is being challenged more broadly within society (Segal, 2007). Architectural practice appears not to have caught up with this changing social trend. As Robert and Simon show, difficulties balancing work and caring responsibilities can have serious consequences including, extended periods of sickness absence. Neither man conformed to the traditional masculine breadwinner model precluding significant involvement in family life (Ford and Collinson, 2011). Their experiences show that studies of masculinities cannot assume that all white, male, middle class, heterosexual professionals are able (or willing) to embody the ideals of hegemonic masculinity. As Whitehead (2002) argued, the accounts presented here demonstrate that structuralist arguments cannot fully explain the perpetuation of inequality of outcome. The individual agency of these men, through their need and desire to undertake caring work for family members marginalised them. 
Managing those working in the creative industries is seen as problematic because of the issues associated with managing individuals whose work involves self-managed creativity (Townley et al., 2009). The literature exploring the management of architectural practices has focussed on the difficulties related to anticipating workflow and cash flow, and the general resistance of architects to being managed (Winch and Schneider, 1993). Despite the clearly gendered norms present within architectural practice, gender has remained invisible from current debates on architectural management. Existing debate on the management of architectural practice have argued that there is a perceived conflict between the creativity of architects and the supposed bureaucracy and inflexibility of management (Emmitt, 1999). There is very little research examining the management of architectural practices (Ram, 1999) or how this perpetuates the gendered norms of the architectural profession, a situation that does not appear to have changed in the intervening years.

Women in the current study reported the homosocial behaviour not only of architects, but also of clients, limiting their access to the social networks necessary for career progression. Sara's account of exclusion from important networking opportunities outside of work demonstrates this homosocial behaviour. This was also an example of a man using a woman's labours as currency with which to improve his social ranking, a key element of homosocial behaviour (Kimmel, 2004). Kanter (1977) developed the theory of homosocial behaviour to explain men's preference for working with other men. Broadbridge and Hearn (2008) highlight the importance of homo-social behaviour to the perpetuation of hegemonic masculinity, particular whereby women are ostracised and undermined. Such homosociality is a key feature of working in the creative industries (Gregory, 2009). More broadly, it demonstrates a certain kind of masculinity is valued, one that centres around alcohol and pub culture, highlighting the existence of a hierarchy of masculinities. Those managing practices 
need to be aware of how these informal networking activities can marginalise women and non-dominant masculinities.

Practice managers need to be aware of the gendered expectations of the architectural profession. If architectural practices are committed to equality and diversity within their organisations then it is important they are aware of how their working practices may marginalise those who are unable to meet them. More broadly, within the creative industries, attention must be paid to how characteristics such as class (McLeod at al., 2009) and gender may intersect to affect entry to the sector (Skilton, 2008) and career progression.

The data presented has shown women, for example, Katie and Vanessa, expressing views and behaviours that perpetuate the existing gendered practices within architecture. There are implications for the architectural profession if women and men who transgress hegemonic masculinity choose to leave. Those who remain will merely reproduce hegemonic masculinities, thereby compromising the profession's abilities to meet the needs of the multiple communities it serves. The male dominated nature of the profession has been linked to the construction of a built environment that perpetuates existing societal and cultural norms (Bonnevier, 2007). Further work is required to understand how the profile of those with responsibility for shaping our built environment influences not only broader societal dynamics, but also the working lives and in turn, (re)produces gender.

Just as organisations are never gender neutral (Acker, 1990), they are not race neutral (Nkomo, 1992). Future studies should examine how class and ethnicity intersect with gender, to understand further, the hierarchy of masculinities and femininities that exist. Doing so would help to understand the continued under-representation of women and ethnic minorities 
within the UK architectural profession and the professions more broadly. Age was alluded to in the current study in the sense that younger female architects may experience problems both for being female and for being young. Given that previous research has demonstrated that older women potentially experience greater discrimination (Moore, 2009), future researchers should consider whether older female architects experience greater or perhaps less discrimination than their younger colleagues. Further work is also needed to understand the heteronormative nature of the assumptions implicit in the organisation of working life, for example, with gay men and lesbian women. This area is under-explored within organisational literature in general (Pringle, 2008) although there is evidence that being openly gay is seen as incompatible with a professional identity (Rumens and Kerfoot, 2009). Further work in this area would help to understand how a wide range of masculinities and femininities are enacted the professions. As the interview with Vanessa demonstrated, there may be tensions between individuals' descriptions of themselves, i.e. as equality champions, and how they organise their own working lives. Research in this area should be aware of this tension and adopt methods to reveal these apparent contradictions.

This article has shed light on some of the gendered norms which are prevalent within the profession largely responsible for shaping the built environment. While women and other marginalised members of the profession continue to experience limitations on their ability to flourish fewer will reach positions that enable them to exert creative power and architectural discourse will continue to be dominated by particular masculine ideals. More broadly this research adds to the debate on masculinities, particularly hegemonic masculinity which thus far, not considered how women may perform their gender in a way that perpetuates hegemonic norms, despite some challenging these norms to improve their own working conditions. Furthermore, this study has given voice to the lived experiences of men, often 
absent in the literature. In addition, discourses around hierarchies of masculinities must move beyond structural analyses that assume that white, heterosexual middle class men can meet the gendered norms expected of them. Rather, insight can be gained from exploration of the role of individual agency and how this can both challenge and reproduce inequalities.

(word length - 7986) 


\section{References}

Acker J (1990) Hierarchies, jobs and bodies: a theory of gendered organizations. Gender and Society 4(2):39-58.

Barrett FJ (1996) The organizational construction of hegemonic masculinity: The case of the US Navy. Gender, Work and Organization 3(3): 129-142.

Bonnevier K (2007) Behind Straight Curtains: towards a queer feminist theory of architecture (Diss.), Stockholm: Axl books.

Boys J (1984) Women in public space. In Matrix, Making space: women and the man-made environment, London: Pluto Press, 40-51.

Bradley HK (2007) Gender. Cambridge: Polity Press.

Broadbridge A and Hearn J (2008) Gender and Management: New Direction in Research and Continuing Patterns in Practice. British Journal of Management 19(1): 38-49

CABE (2005) Black and Minority Ethnic Representations in the Built Environment Professions. Available online at http://webarchive.nationalarchives.gov.uk/20110118095356/http:/www.cabe.org.uk/files/min ority-ethnic-representation-in-the-built-environment-professions.pdf

Cassell C and Lee B (2009). Trade unions learning representatives: progressing partnership? Work, Employment and Society 23(2), 213-230.

Caven V (2005) Constructing a career: women architects at work Career Development International, 9(5): 518-531. 
Cohen L, Wilkinson A, Arnold J and Finn R (2005) 'Remember I’m the bloody architect!'. Work, Employment and Society 19(4): 775-796.

Collinson DL and Hearn J (1994) Naming men as men: implications for work, organization and management. Gender, Work and Organization 1(1), 2-22.

Collinson DL and Hearn J (1996) Breaking the silence: on men, masculinities and managements. In: Collinson DL and Hearn, J (eds.): Men as Managers, Managers as Men. London: Sage, 1-24.

Collinson D L (2003) Identities and insecurities at work. Organization 10(3): 527-547.

Connell RW (1987) Gender and Power: society, the person and sexual politics. Cambridge: Polity.

Connell RW (2002) Gender. Cambridge: UK: Polity Press.

Connell RW and Messerschmidt JW (2005) Hegemonic masculinity: Rethinking the concept. Gender and Society 19(6): 1-31.

Craig L, Powell A, and Cortis N (2012) Self-employment, work-family time and the gender division of labour. Work, Employment and Society 26(5): 716-734.

Crompton R (2010) Class and employment. Work, Employment and Society 24(1): 9-26. 
de Graft-Johnson A, Manley S, and Greed C (2005) Diversity or the lack of it in the architectural profession. Construction Management and Economics 23(10): 1035-43.

de Graft-Johnson A, Manley S, and Greed C (2007) The gender gap in architectural practice: can we afford it, in Dainty, A.R.J., Green, S. and Bagilhole, B. (eds) People and Culture in Construction: A Reader. London: Taylor and Francis: 159-83.

deGraft-Johnson A, Sara R, Greed C and Brkijac N (2009) Gathering and reviewing data on diversity within the construction professions. London: Construction Industry Council.

Demetriou D Z (2001) Connell's concept of hegemonic masculinity: a critique. Theory and Society 30(3): 337-361.

Denissen AM (2010) The right tools for the job: Constructing gender meanings and identities in the male-dominated building trades. Human Relations 63(7):1051-1069.

Dent M and Whitehead S (2002) Managing Professional Identities: Knowledge, Performativity and the 'New' Professional. London: Routledge.

Dick P and Cassell C (2004) The position of policewomen: a discourse analytic study. Work, Employment and Society 18(1): 51-72.

Domosh M (2005) Architecture and Planning. In Blackwell Companion to Gender Studies, edited by Essed P, Goldberg D and Kobayashi A London: Blackwell Publishing, 475-483. 
Donaldson M (1993) What is hegemonic masculinity? Theory and Society 22: 643-57

Emmitt S (1999) Architectural management - an evolving field. Engineering, Construction and Architectural Management 6(2): 188-196

Emslie C, Ridge D, Ziebland S and Hunt K (2006) Men's accounts of depression: reconstructing or resisting hegemonic masculinity? Social Science and Medicine 62 (9): 2246-2257.

Ford J and Collinson D (2011) In search of the perfect manager? Work life balance and managerial work. Work, Employment and Society 25(2): 257-273.

Fournier V and Smith W (2006) Scripting Masculinity. Ephemera: theory and politics in organization 6(2): 141-162.

Fowler B and Wilson F (2004) Women Architects and Their Discontents. Sociology 38(1): 101-119.

Fulcher M (2010). 'Alarm’ as number of women architects falls for first time in nearly a decade. The Architects' Journal. 11 ${ }^{\text {th }}$ November, 2010.

http://www.architectsjournal.co.uk/news/daily-news/alarm-as-number-of-women-architectsfalls-for-first-time-in-nearly-a-decade/8607979.article

Glover J and Kirton G (2006) Women, Employment and Organizations. London: Routledge

Gramsci A (1971) Selections from the Prison Notebooks of Antonio Gramsci New York: International Publishers. 
Greed CH (1994) Women and Planning. Creating gendered Realities. London, UK.: Routledge.

Gregory MR (2009) Inside the Locker Room: Male Homosociability in the Advertising Industry. Gender, Work and Organization 16(3): 323-347.

Guerrier T, Evans C, Glover J and Wilson C (2009) 'Technical, but not very...’: constructing gendered identities in IT-related employment. Work, Employment and Society 23(3): 494511.

Johnson B and Turner LA (2003) Data collection strategies in mixed methods research. In: Tashakkori A and Teddlie C (eds). Handbook of Mixed Methods in Social and Behavioural Research. London: Sage Publications Ltd: 297-319.

Jyrkinin M and McKie L (2012) Gender, age and ageism: experience of women managers in Finland and Scotland. Work, Employment and Society 26(5): 61-77.

Kanter RM (1977) Men and Women of the Corporation. New York: Basic Books.

Kelan E (2008) Gender, risk and employment insecurity: The masculine breadwinner subtext. Human Relations 61(9): 1171-1202.

Kenway J and Fitzclarence L (1997) Masculinity, Violence and Schooling Challenging Poisonous Pedagogies Gender and Education 9(1): 117-133. 
Kimmel MS (2004). Masculinity as homophobia: Fear, shame, and silence in the construction of gender identity. In: Murphy PF (ed). Oxford Readings in Feminism. Oxford: Oxford University Press, 266-287.

King N (2004) Using templates in the thematic analysis of text. In: Cassell C and Symon G (Eds), Essential Guide to Qualitative Methods in Organizational Research London, Sage Publications, 256-70.

Kirton G and Healy G. in press. 'Lift as you rise': Union women's leadership talk. Human Relations published online $15^{\text {th }}$ June, 2012.

Lupton B (2000) Maintaining masculinity: men who do ‘women’s work. British Journal of Management 11: S33-S48.

Martin PY and Collinson D (1999) Gender and Sexuality in Organizations. in Revisioning Gender. In: Ferree M, Lorber J and Hess B (eds). Thousand Oaks, CA: Sage Publications, 285-310.

Matrix (1984). Making space. Women and the man-made environment. London: Pluto Press Ltd.

McLeod C, Donohoe S and Townley B (2009) The elephant in the room? Class and creative careers in British advertising agencies. Human Relations 62(7): 1011-1039. 
Moller M (2007) Exploiting patterns: A critique of hegemonic masculinity Journal of Gender Studies 16(3): 263-276.

Moore S (2009) 'No matter what I did I would still end up in the same position': age as a factor defining older women's experiences of labour market participation. Work, Employment and Society 23(4): 655-671.

Mustchin S (2012) Unions, learning, migrant workers and union revitalization in Britain. Work, Employment and Society 26(6): 951-967.

Ness K (2012) Constructing Masculinity in the Building Trades: 'Most Jobs in the Construction Industry Can Be Done by Women’. Gender, Work and Organization 19(6): 654-676.

Nkomo SM (1992) The Emperor Has No Clothes: Rewriting 'Race in organizations' The Academy of Management Reviews 17(3): 487-513.

Powell A, Bagilhole B and Dainty A (2009) How women engineers do and undo gender: consequences for gender equality, Gender, Work and Organization 16(4): 411-428.

Pringle J (2008) Gender in Management: Theorizing Gender as Heterogender. British Journal of Management,19, Supplement 1: S110-S119.

Pritchard, K and Symon, G (2011) Identity on the line: constructing professional identity in a HR call centre. Work, Employment and Society 25(3), 434-450. 
Pullen A and Simpson R (2009) Managing difference in feminized work: Men, otherness and social practice. Human Relations 62(4): 561-587.

Richards L (1999) Data Alive! The Thinking Behind NVivo. Qualitative health research, 9(3): 412-428.

Rumens N and Kerfoot D (2009) Gay men at work: (Re)constructing the self as professional. Human Relations 62(5): 763-786.

Runte M and Mills AJ (2006) Cold War, chilly climate: Exploring the roots of gendered discourse in organization and management theory. Human Relations 59(5): 695-720.

Sage D and Dainty ARJ (2012) Why Power Matters: Material and Embodied Entanglements of Power in Project-Based Organizations. Engineering, Project Organization Journal 2(4): 202-215.

Schippers M (2007) Recovering the feminine other: masculinity, femininity and the gender order. Theory and Society 36(1):85-102.

Schober P and Scott J (2012) Maternal employment and gender role attitudes: dissonance among British men and women in transition to parenthood. Work, Employment and Society 26(3): 514-530.

Segal L (2007) Slow Motion: Changing Masculinities, Changing Men. Hampshire, UK: Palgrave MacMillan. 
Skilton P F (2008) Similarity, familiarity and access to elite work in Hollywood: Employer and employee characteristics in breakthrough employment. Human Relations 61(12): 17431773.

Smithson J, Lewis S, Cooper C and Dyer J (2004) Flexible working and the gender pay gap in the accountancy profession. Work, Employment and Society 18(1): 115-135.

Stratigakos D (2008) The good architect and the bad parent: on the formation and disruption of its canonical image. The Journal of Architecture 13(3): 283-296.

Townley B, Beech N and McKinlay A (2009) Managing the creative industries: managing the motley crew. Human Relations. 62(7): 939-962.

Truss C, Conway E, d'Amato A, Kelly G, Monks K, Hannon E and Flood P C (2012). Knowledge work: gender-blind or gender-biased. Work, Employment and Society 26(5): 735754.

Waring $\mathrm{T}$ and Wainwright $\mathrm{D}$ (2008) Issues and challenges in the use of template analysis: Two comparative case studies from the field. The Electronic Journal of Business Research Methods 6(1): 85-94.

Watts JH (2007) Porn, pride and pessimism: experiences of women working in professional construction roles. Work Employment and Society 21(2): 299-316. 
Watts JH (2009) Leaders of Men: women 'managing' men in construction. Work Employment and Society 23(3): 512-530.

West C and Zimmerman D (1987) Doing Gender. Gender and Society 1: 121-151.

Whitehead SM (2002) Men and masculinities: Key themes and new directions. Cambridge: Polity.

Winch GM and Schneider E (1993) The strategic management of architectural practice. Construction Management and Economics 11(6): 467-473. 
Author biographies

Katherine Sang is a Lecturer in Management in the School of Management and Languages at Heriot Watt University, Scotland. Based within the Centre for Research on Work and WellBeing, Kate's work focusses on the workplace as the site for the reproduction of gender and associated inequalities. She is the founder of Feminist Academics International and cofounder of Scottish Feminist Academics and is currently co-chair of the Feminist and Women's Studies Association, UK and Ireland.

Andrew Dainty is Professor of the Sociology of Construction and is based in the School of Civil and Building Engineering, Loughborough University, UK. For the past 20 years he has researched the sociologies of construction practice, focusing on the social rules and processes that affect people working as members of project teams. He has also led work mobilising critical perspectives on projects and the management people within the construction sector. He has published over 250 papers and is co-author/editor of seven books and research monographs.

Stephen Ison is a Professor in the School of Civil and Building Engineering Loughborough University. He is an economist with over 25 years experience in Higher Education. His research is in the area of applied economics and policy, in particular transport and labour markets. He has published over 200 papers in the area of applied economics and is author/coauthor/editor of six books. 


\begin{tabular}{|c|c|c|c|c|c|}
\hline $\begin{array}{l}\text { First name } \\
\left({ }^{*} \text { pseudonym) }\right.\end{array}$ & $\begin{array}{l}\text { Age (where } \\
\text { provided) }\end{array}$ & Gender & \begin{tabular}{|l|} 
Relationship \\
status
\end{tabular} & $\begin{array}{l}\text { Primary } \\
\text { Caring } \\
\text { responsibilities }\end{array}$ & Ethnicity \\
\hline Amy & 40s & $\mathrm{F}$ & Single & None & White \\
\hline David (1) & $50 \mathrm{~s}$ & $\mathrm{M}$ & Married & None & White \\
\hline Helen & 30s & $\mathrm{F}$ & Partner & None & White \\
\hline Ian & $30 \mathrm{~s}$ & $\mathrm{M}$ & Married & None & White \\
\hline Marcelle & $30 \mathrm{~s}$ & $\mathrm{~F}$ & Did not say & None & BME \\
\hline Robert & 40s & $\mathrm{M}$ & Married & Yes & White \\
\hline Sara & 30s & $\mathrm{F}$ & Partner & None & White \\
\hline Vanessa* & 50s & $\mathrm{F}$ & Married & Yes & White \\
\hline James & $50 \mathrm{~s}$ & $\mathrm{M}$ & Married & $\begin{array}{l}\text { None, although } \\
\text { does have } \\
\text { children }\end{array}$ & White \\
\hline Rebecca & 30s & $\mathrm{F}$ & Did not say & None & White \\
\hline Vihn* & 30s & $\mathrm{M}$ & Did not say & None & BME \\
\hline Tristan* & 30s & $\mathrm{M}$ & Married & None & White \\
\hline Stephen & 60s & $\mathrm{M}$ & Married & $\begin{array}{l}\text { None, but } \\
\text { returned to } \\
\text { work after } \\
\text { retirement to } \\
\text { support son } \\
\text { through } \\
\text { university. } \\
\end{array}$ & White \\
\hline Katie & $20 \mathrm{~s}$ & $\mathrm{~F}$ & Single & None & White \\
\hline Hussein & 50s & $\mathrm{M}$ & Married & $\begin{array}{l}\text { None, although } \\
\text { does have } \\
\text { children }\end{array}$ & BME \\
\hline David (2) & $50 \mathrm{~s}$ & $\mathrm{M}$ & Married & None & White \\
\hline Chris & 50s & $\mathrm{M}$ & Married & None & White \\
\hline Neil & $40 s$ & $\mathrm{M}$ & Married & None & White \\
\hline Rachel & $30 s$ & $\mathrm{~F}$ & Partner & None & White \\
\hline Musa & 40s & $\mathrm{M}$ & Married & None & BME \\
\hline Simon* & $30 \mathrm{~s}$ & $\mathrm{M}$ & Did not say & Yes & White \\
\hline Jessica* & $30 \mathrm{~s}$ & $\mathrm{~F}$ & Did not say & None & British Jewish \\
\hline Mary* & $30 \mathrm{~s}$ & $\mathrm{~F}$ & Did not say & None & White \\
\hline
\end{tabular}

Table 1. Profile of interview respondents. 